\title{
Value-Added Distribution among Stakeholders Tea Value Chain: A Case Study in Thai Nguyen Province, Viet Nam
}

\author{
Tran Thi Quy Chinh'1,2, Tran Cuong1,3*, Cu Ngoc Bac ${ }^{3}$, Jiancheng Chen ${ }^{1}$ \\ ${ }^{1}$ School of Economics and Management, Beijing Forestry University, Beijing, China \\ ${ }^{2}$ SaoDo University, SaoDo Ward, Socialist Republic of Vietnam \\ ${ }^{3}$ Department of Economic and Rural Development, Thai Nguyen University of Agriculture and Forestry, ThaiNguyen, Socialist \\ Republic of Vietnam \\ Email: info@saodo.edu.vn,dhnl@tuaf.edu.vn, *trancuong@tuaf.edu.vn
}

How to cite this paper: Chinh, T.T.Q., Cuong, T., Bac, C.N. and Chen, J.C. (2021) Value-Added Distribution among Stakeholders Tea Value Chain: A Case Study in Thai Nguyen Province, Viet Nam. Open Access Library Journal, 8: e7508.

https://doi.org/10.4236/oalib.1107508

Received: May 10, 2021

Accepted: June 20, 2021

Published: June 23, 2021

Copyright $\odot 2021$ by author(s) and Open Access Library Inc.

This work is licensed under the Creative Commons Attribution International License (CC BY 4.0).

http://creativecommons.org/licenses/by/4.0/

\begin{abstract}
The article analyzed the added value received by the actors in the Thai Nguyen tea value chain based on the economic chain analysis method including calculation of input costs, added costs, added value, net added value, total profit and total income of each actor and of the entire chain. The results show that the distribution of value added and net added value among actors is uneven, in which farmers receive the largest net value and value added in the chain, but it is the largest effect in the chain. The farmer receives the lowest profit because the farmer's investment cycle is the least. Based on the analysis results of the actual distribution of added value among the actors, the author proposes some solutions to improve the added value that each actor receives when participating in the Thai Nguyen tea value chain.
\end{abstract}

\section{Subject Areas}

Agricultural Engineering

\section{Keywords}

Added Value, Profit, Stakeholders, Value Chain, Tea

\section{Introduction}

Tea production is one of the industries with strength in the Midlands and Mountains in general and in Thai Nguyen in particular. Tea trees have little land disputes with food crops, suitable on sloping land [1]. Tea planting has the effect 
of greening bare land, bare hills and mountains, limiting erosion and leaching. Tea is a crop that can efficiently use the land and hilly climate. Tea development will attract a considerable amount of labor, not only in the production of raw materials, but also in the processing and consumption stages. Therefore, tea development in addition to economic significance also stabilizes the lives and settlements for people by using a lot of local labor to care, harvest, transport, process and consumes tea [2]. Tea tree is really considered a "faithful" friend of farmers [3]. Tea tree in Thai Nguyen province used to be a "tree of poverty alleviation" and is now an "enrichment tree" of many ethnic farmers in Thai Nguyen province [4]. In recent years, Thai Nguyen tea area, yield, quality and value have continuously increased. From 2014 up to now, the tea growing area has been constantly expanding. Along with the application of new varieties in production and the renewal of tea cultivation methods, tea productivity is increasingly improved, tea bud output increases rapidly, gradually meeting the demand for tea production. In 2016, 2017, 2018, 2019, the tea area was 21,520 ha, 22,500 ha, 21,700 ha, 22,300 ha, and the output achieved was 206,400 tons, 215 thousand tons, 212,500 tons, 240 thousand tons [5].

Before the 1990s, most tea was sold to SOEs for preliminary processing and processing, then sold to Vinatea for export. However, in the following years, along with the changes in production, many different forms of tea processing and consumption appeared, such as private processing establishments, semi processing households. variable, private companies, joint ventures processing and exporting tea, households purchasing, wholesaling, etc. Therefore, tea product value chain has been formed and there are many actors involved in the value chain of tea in Thai Nguyen province.

There are many studies on agricultural value chains around the world. Lu [6] evaluated the effectiveness of the vegetable value chain model in China based on the cost aspect, the author conducted an assessment of the production efficiency of farmers in the value chain, operational analysis distribution of intermediary agents in different stages of the chain. Huque [7] clarified in our paper on tea industry value chains in developing countries and related issues from which to propose solutions in contrast to developed countries. The study focused on the factors affecting the tea industry in developing countries and offered solutions to solve those problems. Moreover, the study also focuses on approaching the cost field, one of the measures of cost management. Leahu [8] studied apple value chain in Moldova with the aim of improving the value chain of apples to benefit each chain actor. Accordingly, the research content mainly focused on calculating value add of apple products through each agent from producers to retail agents.

In Vietnam, there have been a number of studies on value chains conducted based on economic and social aspects. Khai [9] conducted research on the Ben Tre coconut value chain, the research contents revolved around the economic and trade relations between value chain actors and the ability to create jobs, in- 
come, and local economic contribution of some key products from coconut trees based on cost-benefit analysis, added value analysis for each stage and the entire value chain according to some key product channels. Son [10] conducted a value chain analysis of apple, garlic and grape products in Ninh Thuan province, focusing on added value analysis, benefit distribution and added value among actors. The ultimate purpose of the study is to improve the economic value of agricultural chains, while increasing income for growers and chain actors. Kiet [11] through the study of the Hoa Loc mango value chain in Dong Thap province shown that shortening the market channel and linking farmers to production helps reduce costs and costs. At the same time, Loc [12] carried out research on dragon fruit value chain in Tien Giang province showed that, dragon fruit farmers are still the most disadvantaged when creating high value but the value received. The fact is always lower than other actors in the chain. Upgrading the value chain and distribution value is more reasonable, the solutions need to be focused to improve the operational efficiency of Tien Giang dragon fruit value chain.

Based on previous studies and local development situation, the author has collected and analyzed the actors in the tea value chain and the distribution of added value among the actors. On the basis of studying the actual situation, the author found that there are some main factors such as: Input suppliers, farmers, fresh tea collectors, processing households, processing enterprises, and wholesale agent, retail agent. Supporting agents such as Department of Agriculture and Rural Development, Department of Trade, NGOs, mass organizations such as Farmers' Union, Women's Union, Youth Union. The analysis results are the premise for the author to propose some solutions to increase added value for actors in the Thai Nguyen tea value chain.

\section{Research Method}

\subsection{Research Data}

Data sampling method: The author distributed questionnaires to 280 tea-growing households, 35 collectors, 14 processing enterprises and 35 tea trader to determine and calculate the added value generated in each stage of the tea industry value chain and the impact of added value on household income. As follows (Table 1):

Use the random sampling method according to the following steps:

- For the agent is a household planting, tending and harvesting tea +Step 1: Select 02 districts, 01 city to investigate: Thai Nguyen city, Dong Hy district, Dai Tu district are the districts and cities with the largest tea acreage in Thai Nguyen province.

+Step 2: Thai Nguyen city selected 3 communes, Dai Tu district and Dong Hy district chose two communes with large tea areas to survey and collect data.

+Step 3: Select the household to survey. The author conducts a sample survey of representative tea growing households serving the calculation of analytical 
Table 1. Subject and sampling survey.

\begin{tabular}{|c|c|c|c|c|c|c|c|}
\hline District & Commune & Village & $\begin{array}{l}\text { No. of surveyed } \\
\text { non poor } \\
\text { households }\end{array}$ & $\begin{array}{l}\text { No. of surveyed } \\
\text { poor households }\end{array}$ & $\begin{array}{l}\text { No. of surveyed } \\
\text { tea collecter }\end{array}$ & $\begin{array}{c}\text { No. of } \\
\text { surveyed tea } \\
\text { processor }\end{array}$ & $\begin{array}{c}\text { No. of } \\
\text { surveyed tea } \\
\text { trader }\end{array}$ \\
\hline \multirow{3}{*}{$\begin{array}{c}\text { Thai Nguyen } \\
\text { city }\end{array}$} & Tan Cuong & Hong Thai 1 & 30 & 10 & 5 & 2 & 5 \\
\hline & Phuc Xuan & Trung Tam & 30 & 10 & 5 & 2 & 5 \\
\hline & Phuc Triu & Lai Thanh & 30 & 10 & 5 & 2 & 5 \\
\hline \multirow{2}{*}{ Dai Tu district } & La Bang & La Bang & 30 & 10 & 5 & 2 & 5 \\
\hline & Yen Lang & Đong Đinh & 30 & 10 & 5 & 2 & 5 \\
\hline \multirow{3}{*}{$\begin{array}{c}\text { Dong Hy } \\
\text { district }\end{array}$} & Trai Cai & Trai Cai 1 & 30 & 10 & 5 & 2 & 5 \\
\hline & Van Han & Van Han 1 & 30 & 10 & 5 & 2 & 5 \\
\hline & Total & & 210 & 70 & 35 & 14 & 35 \\
\hline
\end{tabular}

Source: Author proposed.

criteria to implement the research content of the topic; through direct communication, observing reality.

Selection of survey households: Due to the time, budget and support staff, we randomly selected 30 non-poor households and 10 poor households in each communes.

- For actors who are tea collectors:

For this actor, the author randomly selects 05 people/01 commune having commercial activities in the form of collection to conduct investigation, interview to get information, calculation data.

- For agents being agents that are tea processing establishments: For this actor, the author randomly selects 02 people/01 commune to investigate, interview to get information and calculation data for research.

- For the stakeholder who is the dry tea sellers: The author chooses the large and stable business households. Each commune conducted to select 5 tea traders/01 commune.

- For supporting actors: The author conducts in-depth interviews with officials from Thai Nguyen Tea Association, Farmers Association, Policy Bank of Thai Nguyen City, Dong Hy District, Dai Tu District.

\subsection{Analysis Methods}

The study uses the calculation method of the value-added distribution rate and the marginal rate of profit in the value chain proposed by Pavithra, Parmar [13] [14] to analyze the status of profit distribution among actors in the chain value of tea in Thai Nguyen. The key data in the research results are calculated as follows:

- Calculating cost and profit margins: Figures for calculating cost and profit margins per actor are averaged in 2019.

- The calculation of the value-added distribution rate and the rate of return in the value chain are presented in Table 2. 


\section{Result and Discussion}

\subsection{The Tea Value Chain}

The tea value chain can be described as a series of activities that create and value tea from tea planting, tending and collection, raw processing, deep processing and distribution, and consumption of tea on the market with the participation of all stakeholders from tea farmers to processing companies, trading companies and distributing tea products to consumersb [15]. The tea value chain is depicted below (Figure 1).

Actors are those who perform the functions of all stages in the chain, such as suppliers of inputs to tea production, tea cultivation, tea traders, tea processors, purifiers and packers, vendors, wholesale and retail sales of tea to consumers [16]. There are also value chain supporters, whose task is to help the chain grow by facilitating value chain upgrades.

- Tea farmers: This is the stage that creates a low added value in the tea value chain.

Table 2. Calculation method of the value-added distribution rate and the margin of profit margin in the value chain.

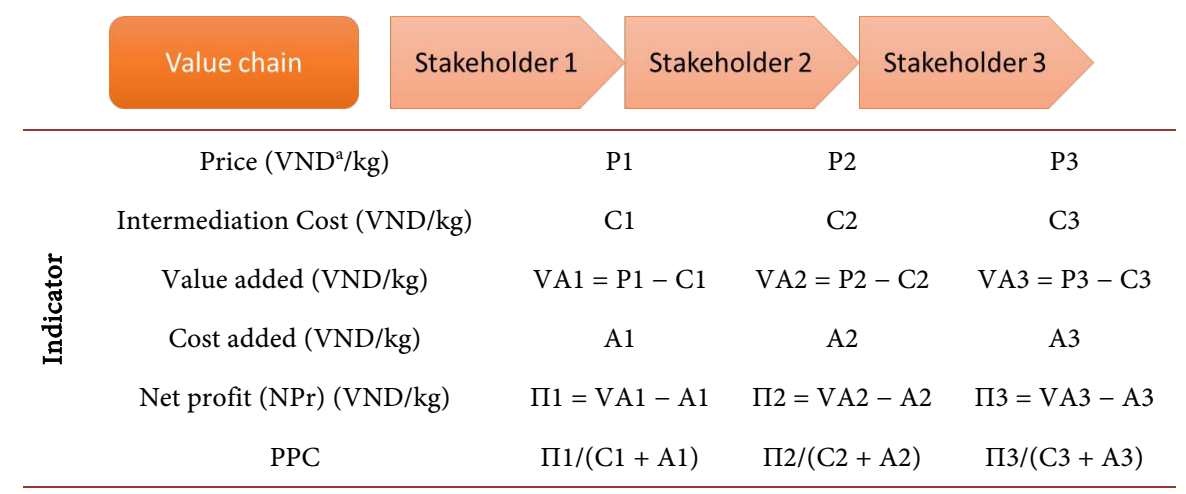

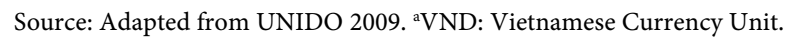

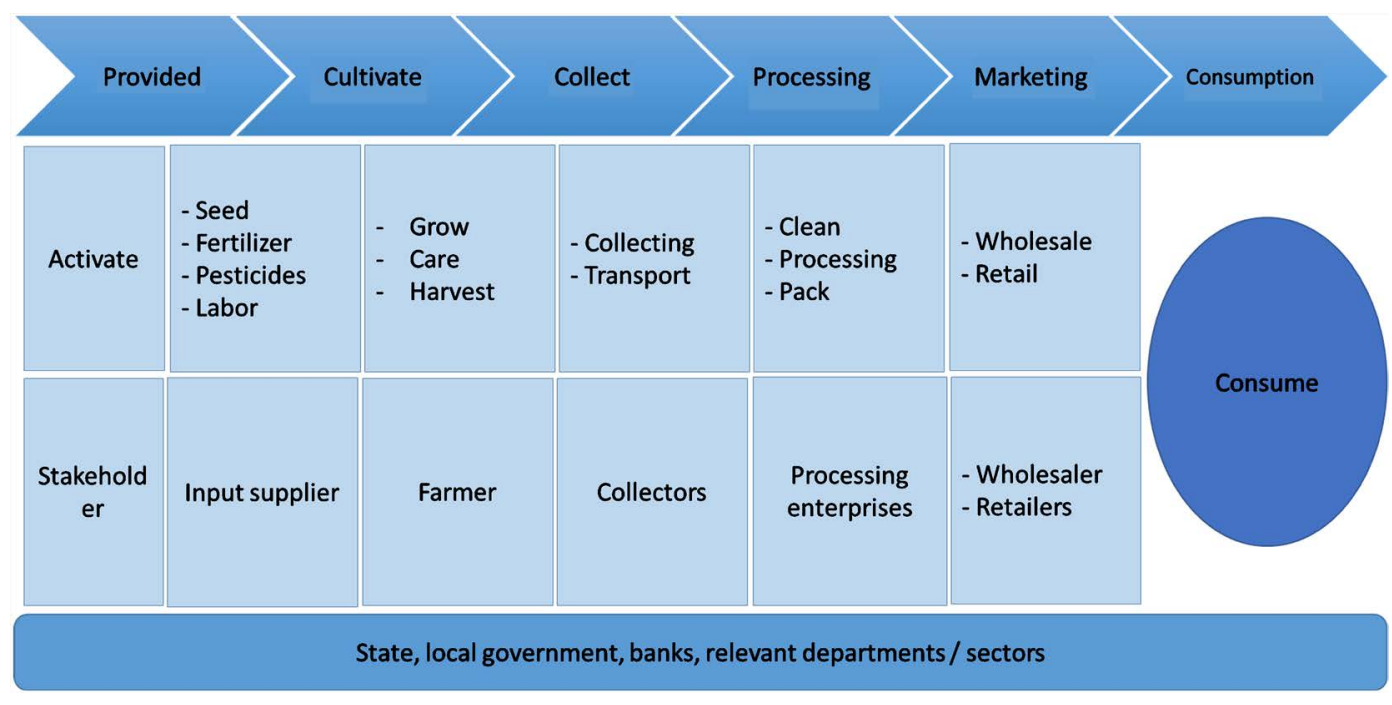

Figure 1. Tea value chain. 
- Collectors: This is the stage that creates the average added value in the tea value chain.

- Tea processing companies: This is the stage that creates high added value in the tea value chain.

- Export/import enterprise: This is the stage that creates an average added value in the tea value chain.

- Direct retailers: This is the stage that creates an average added value in the tea value chain.

\subsection{Participating Actors and Support Agents into the Tea Product Value Chain}

\subsubsection{The Agent Provides the Inputs}

\section{1) Seedling supply agent}

Thai Nguyen land is famous for tea, called with the name "First name tea". Thai Nguyen people are also much attached to the cultivation and processing of tea products. Tea varieties grown in different regions of the province are also different and diverse in types [17]. In Thai Nguyen, tea seed nursery is strictly monitored, the unit that controls the quality of the elite tea garden and original seed orchard is the Plant Protection and Cultivation Department. Once the nursery is certified, the Provincial Tea Project Management Unit organizes a tender to formulate contracts for the local seed supply.

\section{2) Supplying agricultural materials agents}

In tea material areas, about $60 \%$ of agricultural material agents specialized in supplying fertilizers and pesticides to tea growers are secondary agents, the rest are tier 1 agents. Agro-material agents have a long-term relationship with farmers, therefore, each farmer usually chooses 1 to 2 agricultural material agents supplying fertilizers and pesticides. In addition to providing agricultural materials, these agents also provide market information (buyers, tea prices, etc) and provide technical advice on tea production to farmers. Besides, most agricultural material agents provide "commercial credit" to tea-producing farmers. Thai Nguyen province currently has over 710 plant protection establishments, 850 fertilizer establishments.

\section{3) Labor is hired in the value chain}

Tea production is one of the jobs that is quite arduous and labor intensive [18]. In the context of limited mechanization of tea cultivation, hired labor is the source of labor for tea production from planting, tending to harvesting. Through field surveys, the care and collection stage is the most labor intensive stage in the production process. However, the number of family workers of most farmers participating in tea cultivation is still small compared to the production scale, so farmers often have to hire more labors. Therefore, farmers have to hire middle-aged workers or in other localities, so the labor renting price is usually very high, the average cost of labor is $120,000 \mathrm{VND} /$ day. One working day in the study area is counted as 5 to 6 hours. 


\subsubsection{Farmers}

The tea value chain of farmers is formed based on economic relationships with input providers, output agents and groups of actors that play a supporting role [19]. The group of agents providing inputs include: agricultural material agents, seed production establishments, and hired labor (Figure 2).

The determination of the costs related to the tea production activities of the farmer is very important because this is the basis for calculating the costs and the profit of the producer.

As shown in Table 3, intermediate cost: Average intermediate cost calculated per $1 \mathrm{~kg}$ of tea of a farmer is $2832.8 \mathrm{VND}$, including: cost of manure, cost of fertilizers, pesticides and fuel costs. In which, the cost of fertilizers and chemicals accounts for the highest proportion.

Additional cost: Is the added cost in production activities of tea growers. The additional cost per $1 \mathrm{~kg}$ of tea of the farmer household is $2414 \mathrm{VND}$, including: Family labor costs, hired labor costs, depreciation costs for machinery, interest expenses, construction costs. In which, labor cost accounts for the largest proportion. The calculation results show that with the tea selling price of 9125 $\mathrm{VND} / \mathrm{kg}$, the added value of tea farmers is $6292.2 \mathrm{VND} / \mathrm{kg}$ and the net added value is 3878.2 .

\subsubsection{Traders of Fresh Tea}

Collector's scope of activity is limited to Thai Nguyen province. The collectors buy fresh tea from farmers and then sell the tea to dry tea processors, wholesalers and retailers (Figure 3).

For collectors, their business costs are mainly tea purchase costs and handling costs. If calculated on $1 \mathrm{~kg}$, the cost of buying tea accounts for $95.6 \%$ and the

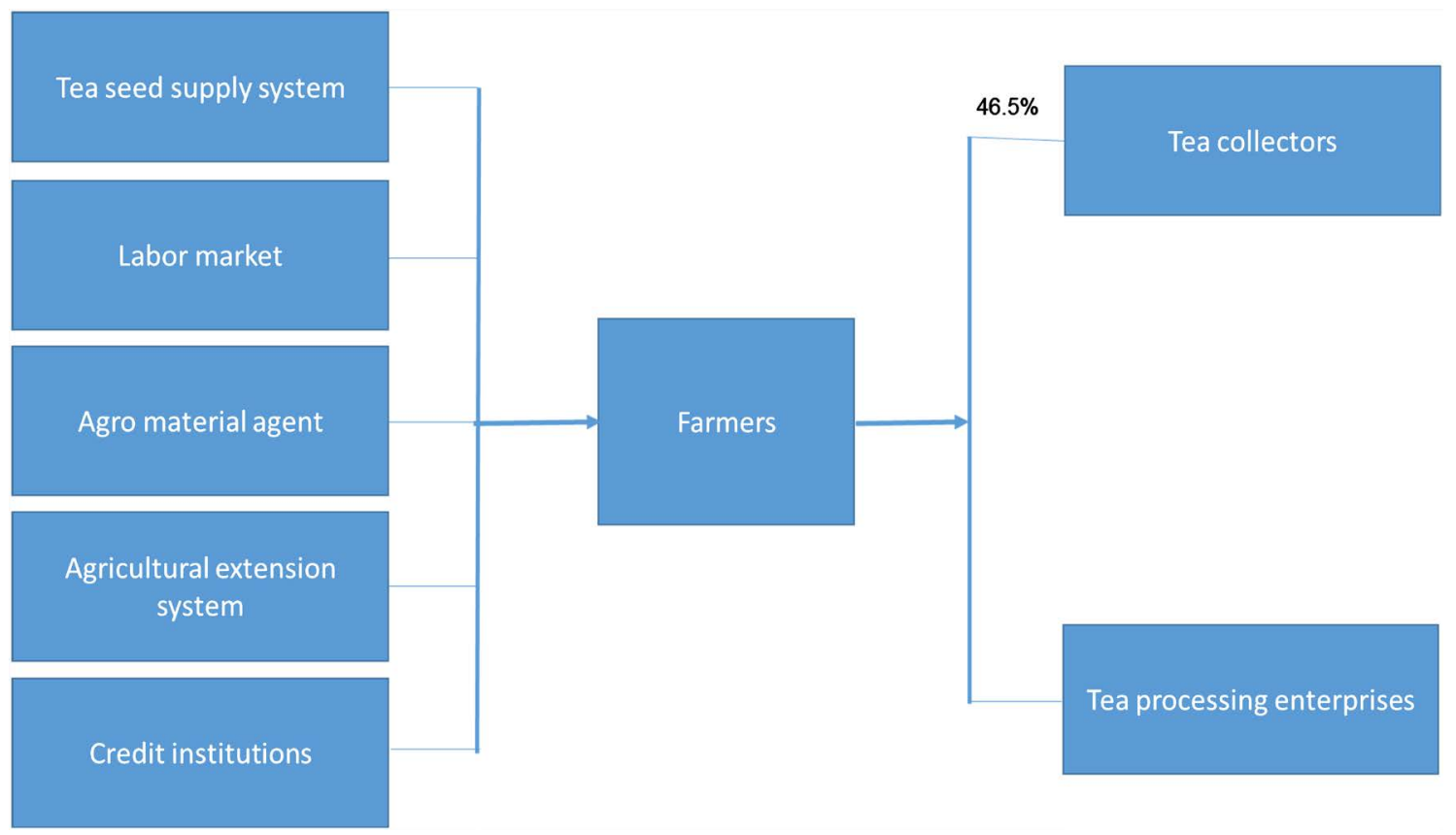

Figure 2. Map of tea product value chain of farmers. 
Table 3. Turnover, cost and added value of tea farmers.

\begin{tabular}{cccc}
\hline No. & Indicators & Value (VND/kg) & Portion (\%) \\
\hline \multirow{4}{*}{ Gross output (GO) } & 9125 & \\
& Intermediational Cost (IC) & $\mathbf{2 8 3 2 . 8}$ & 31.04 \\
+ Fertilizer & 791.5 & 8.67 \\
+Manure & 895.6 & 9.81 \\
+Pesticides & 160.6 & 1.76 \\
+Fuel & 860.7 & 9.43 \\
+Others material & 124.4 & 1.36 \\
Value added (VA) & 6292.2 & 68.96 \\
Cost added & 2414 & 26.45 \\
Labor cost & 1868 & 20.47 \\
& Debt interest payment & 63.1 & 0.69 \\
Machine depreciation & 26.4 & 0.29 \\
Basic construction costs & 456.5 & 5.00 \\
+Net profit (NPr) & 3878.2 & \\
\hline
\end{tabular}

Source: Survey data, 2019.

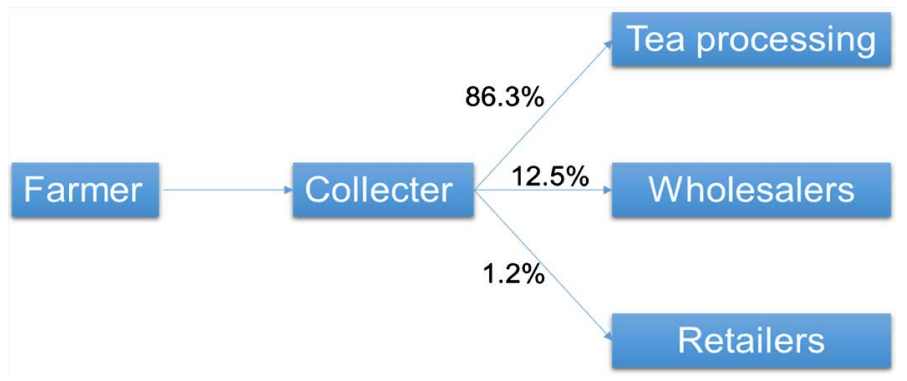

Figure 3. The collector's value chain diagram.

cost of loading and unloading makes up $4 \%$ of the total cost of tea business. The remaining costs account for a small proportion in the cost structure.

As shown in Table 4, when the average selling price of tea collectors to tea processors is $9855.2 \mathrm{VND} / \mathrm{kg}$, with the total cost of tea collection activities of 9557.66, the collectors enjoy the added value of $297.54 \mathrm{VND} / \mathrm{kg}$.

\subsubsection{Processing Agent}

Processors in the value chain play an important role in enhancing the added value of tea through processing activities (Figure 4). After purchasing tea from fresh tea traders, the processing establishments will process tea. The process of processing fresh tea into black tea is quite complicated, including many different stages, requiring processing establishments to invest in equipment and machines, and also have good skills in tea drying.

Tea processing activities are quite complicated, requiring processors to invest in machinery and equipment such as crusher, drying oven, packaging machine, 
Table 4. Revenue, cost, profit, added value of tea collecter.

\begin{tabular}{cccc}
\hline No. & Indicators & Value (VND/kg) & Portion (\%) \\
\hline \multirow{4}{*}{$A$} & Gross output (GO) & 9855.2 & \\
& Intermediational Cost (IC) & 9323.23 & 97.55 \\
+ Cost of buying tea & 9125 & 95.47 \\
+ Fuel & 198.23 & 2.07 \\
Value added (VA) & 531.97 & 5.57 \\
Cost added & 234.43 & 2.45 \\
& Labor cost & 185.04 & 1.94 \\
& Debt interest payment & 12.3 & 0.13 \\
Machine depreciation & 35.23 & 0.37 \\
& Product depreciation cost & 0.55 & 0.01 \\
Taxes and fees & 1.31 & 0.01 \\
Net profit (NPr) & 297.54 & \\
\hline
\end{tabular}

Source: Survey data, 2019.

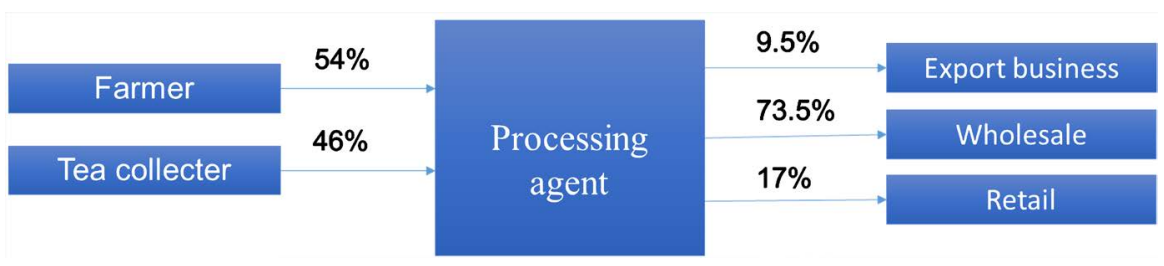

Figure 4. Value chain map of tea processors.

ect. To be able to invest in tea processing machines many households have to borrow from the Bank. Households and large-scale processing enterprises have to hire more workers to perform different processing stages.

- Cost of raw material: This is the expense that accounts for the largest proportion in the cost structure of tea-processed products. Besides tea purchase costs, raw material costs also include the cost of some additives to the product. This cost accounts for $79.2 \%$ of the production cost structure.

- Labor cost: Labor cost accounts for a significant proportion in the cost structure of processed products (11.2\%). Processing businesses pay labor costs by product and by production stage. The workers in the tea drying stage will receive higher remuneration compared to the workers performing the packaging. For the households, mainly using family labor, and at the same time, they will hire outside workers when production is high. For businesses, the number of employees is usually fixed, businesses will choose skilled and skilled workers at important stages in the processing process.

- Fuel cost: Machines need to be used to process tea, which consumes a great deal of electricity and coal and firewood. The consumption of raw materials required for the production of $1 \mathrm{~kg}$ of fresh tea is $687.4 \mathrm{VND}$.

- Depreciation of machinery: This is also a significant cost in the structure of 
tea processing costs. The fermentation machines, the crusher, the tea leaf drying conveyor, and the tea dryer all have certain lifespans and are gradually amortized over time.

- The remaining costs include: transportation costs, management costs, interest expenses and storage and storage costs and tax costs contribute to the cost structure of tea processed products.

The result of the processing process will result in dry tea product (Table 5). It is estimated that $5 \mathrm{~kg}$ of fresh tea produces $1 \mathrm{~kg}$ of dry tea. So, with the average price of $1 \mathrm{~kg}$ of dry tea being 76,130 which means 15,226 VND/kg of fresh tea, the profit generated by the processors is $2751.4 \mathrm{VND} / \mathrm{kg}$.

\subsubsection{Commercial Agent}

\section{1) Wholesalers}

A very important link between the processor and the factory/exporter or retailer is the dry tea trader. They buy dried tea from producers and sell them to factories/exporters located within the province or other provinces. Dry tea merchants' network is quite large. They can sell to companies/factories in the province but also sell to other provinces across the country. They sell tea to traders to sell to other provinces, Figure 5 is a chain diagram of a dried tea trader.

Compared with fresh tea traders, the survey results in Thai Nguyen show that dry tea traders require more capital than fresh tea traders. In addition, the sales

Table 5. Revenue, cost, profit, added value of tea processors.

\begin{tabular}{cccc}
\hline No. & Indicators & Value (VND/kg) & Portion (\%) \\
\hline \multirow{4}{*}{ Gross output (GO) } & 15,226 & \\
& Intermediational Cost (IC) & $12,474.6$ & 87.76 \\
+ Cost of raw material & 9834.5 & 69.19 \\
+ Other costs & 154.7 & 1.09 \\
+ Fuel & 687.4 & 4.84 \\
+Others material & 58.6 & 0.41 \\
Value added (VA) & 4490.8 & 31.59 \\
Cost added & 1739.4 & 12.24 \\
Labor cost & 1400.2 & 9.85 \\
& Debt interest payment & 18.7 & 0.13 \\
& Machine depreciation & 200.5 & 1.41 \\
& Product depreciation cost & 120 & 0.84 \\
+Net profit (NPr) & 2751.4 & \\
\hline
\end{tabular}

Source: Survey data, 2019.

$\begin{gathered}\text { Processing } \\ \text { households }\end{gathered} \quad \begin{gathered}\text { Traders in the } \\ \text { province }\end{gathered}, \begin{gathered}\text { Traders outside } \\ \text { the province }\end{gathered}$

Figure 5. Simplified chain of dry tea traders. 
network of dried tea traders is also wider. The main customers of the dried tea traders are companies and traders in other provinces. In tea trading, dry tea traders often face many difficulties such as fluctuating prices, no reserves, and lack of capital. Besides, the debts that the buyers do not pay also bring great risks to the dried tea traders. In addition to the development of processing technology, the explosion of mass media such as telephones and the Internet as well as innovative modes of transport have also had a major impact on business.

According to our survey, most traders sign contracts with customers and purchase agreements over the phone. With the average dry tea collection price of $18,230 \mathrm{VND} / \mathrm{kg}$, the cost to be spent on the collection is $15,560 \mathrm{VND} / \mathrm{kg}$ (this includes manpower and fuel costs for transport vehicles., when tea wastage, preservation costs ...), the profit generated by dry tea merchants is about 2000 $3000 \mathrm{VND} / \mathrm{kg}$ (Table 6). On average, traders get 3 to 10 tons of dry tea annually.

\section{2) Domestic retailers}

Retail agent is the person who directly distributes tea products to the end consumers. The primary market for retail agents is wholesalers. In the survey results, most retailers are women (accounting for 62.16\%), the average age of the retailer is 42 years old with an education level of about grade 8 . Experience in tea trading 6 years of retail, who has 29 years most retail experience.

According to the survey results, the total retail cost for the buying tea is 18,253 , accounting for $75.4 \%$ (Table 7). In order to sell tea, retailers often have to rent in locations with good business premises, so the cost for this item is quite large, equivalent to the cost of hiring the salesman. According to the calculation results, after subtracting the value added expenses that tea retailers receive is $1421 \mathrm{VND} / \mathrm{kg}$ tea. On average, each retailer can sell $500 \mathrm{~kg}$ of tea a month, and the estimated retail profit is 6.4 million/month. This is the level of profit commensurate with the size of the retailer's business investment.

Table 6. Revenue, cost, profit, added value of tea wholesaler.

\begin{tabular}{cccc}
\hline No. & Indicators & Value (VND/kg) & Portion (\%) \\
\hline \multirow{4}{*}{$A$} & Gross output (GO) & 18,663 & \\
& Intermediational Cost (IC) & $15,459.4$ & 99.98 \\
+ Cost of raw material & 15,227 & 1.53 \\
+ Other costs & 232.4 & \\
& Value added (VA) & 3203.6 & 0.02 \\
B & Cost added & 2457 & 8.16 \\
& Labor cost & 1243 & 4.30 \\
& Debt interest payment & 654.3 & 2.28 \\
Sorage cost & 346.5 & 1.52 \\
& Marketing cost & 231.2 & 4.79 \\
\hline
\end{tabular}

Source: Survey data, 2019. 
Table 7. Revenue, cost, profit, added value of tea retailers.

\begin{tabular}{|c|c|c|c|}
\hline No. & Indicators & Value (VND/kg) & Portion (\%) \\
\hline \multirow{4}{*}{$A$} & Gross output (GO) & 26,253 & \multirow[b]{2}{*}{74.73} \\
\hline & Intermediational Cost (IC) & 18,557 & \\
\hline & & & \\
\hline & + Cost of raw material & 18,253 & 73.51 \\
\hline \multirow{9}{*}{$B$} & +Other costs & 304 & 1.22 \\
\hline & Value added (VA) & 7696 & 30.99 \\
\hline & Cost added & 6275 & 25.27 \\
\hline & Labor cost & 1540 & 6.20 \\
\hline & Debt interest payment & 1086 & 4.37 \\
\hline & Machine depreciation & 643 & 2.59 \\
\hline & Marketing expense & 420 & 1.69 \\
\hline & Cost rent & 1500 & 6.04 \\
\hline & + Net profit (NPr) & 1421 & \\
\hline
\end{tabular}

Source: Survey data, 2019.

\section{3) Exporters}

Currently, about $20 \%$ of tea production in Thai Nguyen is exported. In which, tea exports are mainly through two main channels:

According to VITAS statistics in 2018, there are currently about 240 tea exporting companies. This figure is higher than Vietnam's rice and coffee exporters. Nearly 100 out of the 240 companies mentioned above specialize in the tea trade, the rest exporting tea accounts for a small portion. Tea can be exported through 3 channels:

- Through state-owned enterprises (mainly through VINATEA).

- Through joint ventures and foreign companies.

- Through private companies (including limited liability companies and joint stock companies).

\subsubsection{Agents Supporting Tea Product Value Chain}

\section{1) VITAS}

VITAS is an organization created by members including all actors in the tea industry to develop the tea industry in Vietnam. According to a report by ADB (2004) [3], the capital of the organization comes from the annual contribution fee, of 67 members, of which $41 \%$ come from VINATEA [20], 45\% from provincial companies and $14 \%$ from farmer associations. People with less than 5 hectares of tea plantation can join the association for free, but the progress of joining is very slow. Research by ADB identifies association members as SOEs and requires larger committees to make a significant contribution to the fostering and development of new businesses or innovations. in distribution. The Vietnam Tea Association (VITAS) was one of the first associations in Vietnam, estab- 
lished on January 25, 1998 [21]. Starting with 16 members, VITAS currently has 200 members located in 10 locations and 34 tea growing provinces.

\section{2) Agricultural extension association}

Extension services for tea farmers are provided by VINATEA and factories or by provincial departments of agriculture to non-affiliated small-scale households. Analyzing these services, ADB (2000) concludes: "The effectiveness of the extension workers is limited because of the low wages and the transport of themselves. The training and training of agricultural advisors are only rudimentary due to lack of capital and practice. Extension services are mainly focused on farming techniques but have not yet expanded to processing and marketing. "In contrast, farmers on farms receive more attention in meeting all of their needs.

\section{3) Credit institutions}

In order to help farmers, as well as actors in the value chain, have capital to ensure their operations. Credit institutions, mainly Bank for Social Policies, Bank for Agriculture and Rural Development always create the most favorable conditions for farmers, especially poor farmers to access official credit. The District Social Policy Bank regularly implements programs to lend money to poor and near-poor households to grow tea. For support program for poor and near poor households, each household can borrow at least 20 million and a maximum of 50 million, these households can borrow money based on unsecured. For the Bank for Agriculture and Rural Development, regularly organizing loans to farmers at interest rates to support agricultural development. Support other actors in the value chain to access loans with the simplest conditions and procedures.

Tea distribution chain of farmers in Thai Nguyen is illustrated in the following diagram (Figure 6).

Thus, we can see the main market channels in the value chain of tea products:

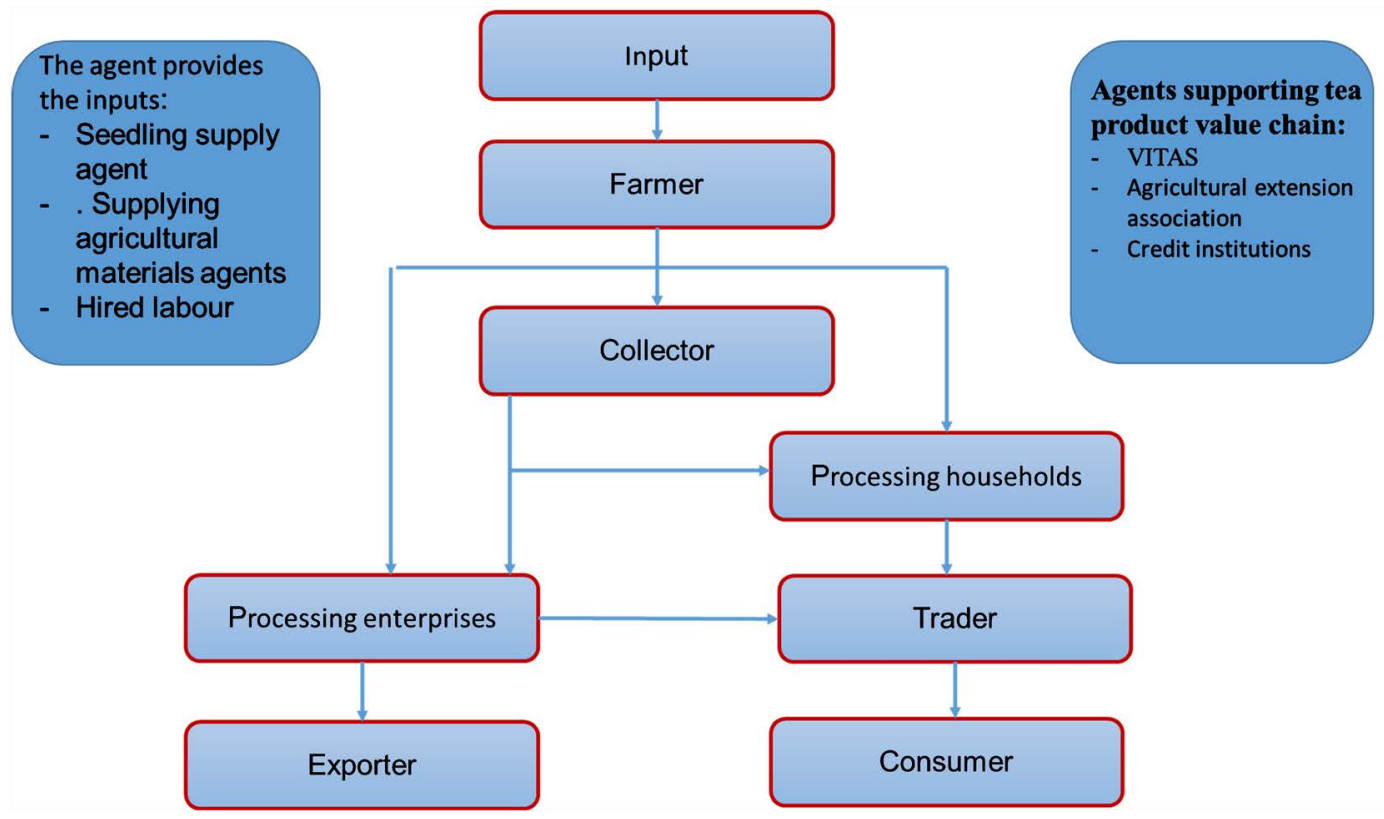

Figure 6. Tea distribution chain of farmers in Thai Nguyen. 
- Distribution channel 1: Farmer - Collecter - Processor - Wholesale - Retailer - Consumer.

- Distribution channel 2: Farmer - Collecter - Processor - Extorter.

- Distribution channel 3: Farmer - Processor - Wholesale - Retailer - Consumer.

- Distribution channel 4: Farmer - Processor - Extorter.

\subsection{Value-Added Distribution for Actors in the Value Chain}

In the main market channels of tea products, each actor will create different added value:

- Farmers: Farmers are the agents that play a production role, creating the first added value for tea products in the value chain. The added value that farmers create in market channels is not high, ranging from 2500 to $2970 \mathrm{VND} / \mathrm{kg}$. In channel 4, the added value of farmers is highest when directly selling tea to tea processors for export purposes. The added value created is the highest but the product requirements are also the highest.

- Collecter: This is the agent that only appears in channel 1 and channel 2. The added value that these actors receive is not much, so in addition to fresh tea collection, they also participate in other labor activities, or in other words, tea collection is only a secondary source of their income. The value added they receive in the tea value chain is only about $309.79 \mathrm{VND} / \mathrm{kg}$.

- Processor: The processing house is an agent contributing to the added value of tea products through processing and exporting activities. At the same time, the agent is present in all tea product distribution channels. Because most of the tea is grown, it is processed into dried pies before it reaches the consumer. The added value that this actor receives in the tea value chain is from 2500 to $3000 \mathrm{VND} / \mathrm{kg}$. According to the survey results, if the processors directly buy tea materials from farmers, they will receive a higher added value.

- Wholesaler: Being a commercial agent plays an important role in the distribution of tea to many domestic markets. The wholesalers who can ship tea for sale to retailers within the province can also ship tea outside of Thai Nguyen province. Their range of activity is very wide from 5 to $1000 \mathrm{~km}$. Thanks to this network, Thai Nguyen tea is present in all provinces in the country. The added value created by this agent in the market channels is 3420 $\mathrm{VND} / \mathrm{kg}$.

- Retailer: In the domestic market, retail is the agent that brings tea products to consumers. In market channels, the added value created by retailers ranges from 5450 - $5560 \mathrm{VND} / \mathrm{kg}$.

Based on Table 8 shows that the revenue generated in the whole chain is $78,795.2 \mathrm{VND} / \mathrm{kg}$, the added value generated in the whole chain is $22,214.57$ $\mathrm{VND} / \mathrm{kg}$. In which retailer is the object creating the largest added value compared to other factors (accounting for 34.64\%). Farmer is the second largest 
Table 8 . The value added, the ratio value added to the stakeholders.

\begin{tabular}{|c|c|c|c|c|c|c|c|c|}
\hline \multirow[b]{2}{*}{ Indicator } & \multicolumn{3}{|c|}{ Tea plantation } & \multirow[b]{2}{*}{ Collecter } & \multirow[b]{2}{*}{ Prossesor } & \multicolumn{2}{|c|}{ Trader } & \multirow[b]{2}{*}{ Value chain } \\
\hline & Farmer & $\begin{array}{l}\text { Non poor } \\
\text { household }\end{array}$ & $\begin{array}{c}\text { Poor h } \\
\text { ousehold }\end{array}$ & & & Wholesaler & Retailer & \\
\hline Gross output $(\mathrm{GO})^{(1)}$ & 9125 & 9134 & 9124 & 9855.2 & 15,226 & 18,336 & 26,253 & $78,795.2$ \\
\hline Intermediation Cost (IC) $)^{(2)}$ & 2832.8 & 2789.3 & 2967.3 & 9323.23 & $12,474.6$ & $15,459.4$ & 18,557 & $58,647.0$ \\
\hline Value added ${ }^{(3)}$ & 6292.2 & 6344.7 & 6156.7 & 531.97 & 4490.8 & 3203.6 & 7696 & $22,214.57$ \\
\hline$\%$ Value added ${ }^{(4)}$ & 28.32 & 28.56 & 27.71 & 2.39 & 20.22 & 14.42 & 34.64 & 100.00 \\
\hline Addition $\operatorname{cost}^{(5)}$ & 2414 & 2414.1 & 2414.5 & 234.43 & 1739.4 & 2457 & 6275 & $13,119.83$ \\
\hline Net value added ${ }^{(6)}$ & 3872.2 & 3930.6 & 3742.2 & 297.54 & 2751.4 & 729 & 1421 & 9071.14 \\
\hline$\%$ Net value added ${ }^{(7)}$ & 42.69 & 43.33 & 41.25 & 3.28 & 30.33 & 8.04 & 15.67 & 100.00 \\
\hline Total cost ${ }^{(8)}$ & 5246.80 & 5203.40 & 5381.80 & 9557.66 & $14,214.00$ & $17,916.40$ & $24,832.00$ & \\
\hline $\mathrm{PPC}^{(9)}$ & 0.738 & 0.755 & 0.695 & 0.031 & 0.194 & 0.041 & 0.057 & \\
\hline
\end{tabular}

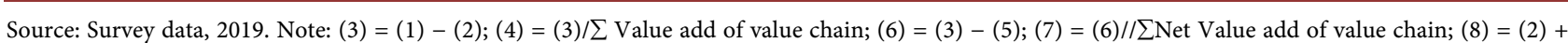
(5); (9) = (6)/(8).

value added in the chain $(28.32 \%)$. The added value of the non-poor is higher than the added value of the poor, mainly because the non-poor can save more on cultivation costs than the poor. Fresh tea collectors are the agents with the lowest value-added ratio, accounting for only $2.39 \%$. In terms of net added value, farmers are the actors with the highest percentage in the whole chain $(42.69 \%)$, followed by tea processors (30.33\%), fresh tea collectors (3.28\%) are still the actors with the lowest percentage. However, this stakeholder's activity is also the simplest activity in the chain's activities; sometimes they do not have to invest capital but directly buy fresh tea from farmers and then transfer it directly to the processing units. The job requirement for this object is to transport quickly because tea after picking must be processed within 3 - 5 hours. The results also showed that of all the actors participating in the value chain, the farmer household is the one with the highest profit/cost ratio, of which the non-poor has the rate of return profit/cost is higher than poor households. With 1 VND of investment cost, poor households generated 0.695 VND profit, while non-poor households generated $0.755 \mathrm{VND}$ profit. However, in order to accurately assess the efficiency of investment in production and business of each agent, it is necessary to consider the rate of return/year and tea production/transaction in the year of each agent.

According to calculation results (Table 9), although farmers are the agents that create the highest profit/cost ratio, they only return three times of capital in 1 year. Meanwhile, other actors have a much larger number of capital cycles than farmers. Moreover, with a very large volume of transactions, commercial agents are many times more effective subjects than farmers. On the other hand, if comparing the rates of return/year of actors participating in the value chain compared to the opportunity costs of investing in banks, the financial efficiency of actors participating in the value chain is very high. 
Table 9. Investment efficiency of actors participating in the tea value chain.

\begin{tabular}{cccccc}
\hline Stakeholder & $\begin{array}{c}\text { Profit } \\
\text { margin }\end{array}$ & $\begin{array}{c}\text { Capital } \\
\text { turnover/year }\end{array}$ & $\begin{array}{c}\text { Output } \\
\text { (tons/year) }\end{array}$ & $\begin{array}{c}\text { Profitability/ } \\
\text { year }^{(2)}\end{array}$ & $\begin{array}{c}\text { Bank interest } \\
\text { rate/year }^{(3)}\end{array}$ \\
\hline Poor household & 0.695 & 3 & 10.5 & 2.085 & 0.07 \\
Non poor household & 0.755 & 3 & 17.7 & 2.265 & 0.07 \\
Collector & 0.031 & 85 & 256.4 & 2.635 & 0.07 \\
Prosessor & 0.194 & 45 & 1670.5 & 8.73 & 0.07 \\
Wholesaler & 0.041 & 84 & 380.9 & 3.444 & 0.07 \\
Retailer & 0.057 & 68 & 5.7 & 3.876 & 0.07 \\
\hline
\end{tabular}

Source: Survey data, 2019. Note: (1)Number of capital cycles/year $=$ Number of days of operation in the year/number of days of capital turnaround; ${ }^{(2)}$ Rate of return/year $=$ Rate of return ${ }^{*}$ Number of capital cycles/year; ${ }^{(3)}$ Interest is charged for the 12 -month term.

\section{Conclusions}

Studying the activities of actors participating in the value chain of tea products, at the same time analyzing the added value and the distribution of value added among actors participating in the tea product value chain. Some conclusions are drawn as follows:

First, the value chain of tea products in Thai Nguyen province has four main market channels. Tea products from farmers through agents and to domestic consumers account for $80 \%$ of the total tea output that the farmer has harvested. Almost all actors participating in the value chain have positive investment efficiency. This shows that Thai Nguyen tea is not well known to the world, so it is necessary to have policies to promote Thai tea exports to foreign markets and enhance the Thai Nguyen tea brand.

Second, in all major market channels, the added value of tea produced by poor farmers and the added value received by poor farmers is always lower than that of non-poor farmers. In fact, the survey shows that production resources of poor households are still limited: low education, lack of production techniques, lack of financial resources. Lack of financial advantage makes poor households lose their negotiating position when buying inputs. Buying agricultural materials and paying at different times make the prices of using inputs soar. At the same time, compared to non-poor households, poor households are also weak in the relationship of negotiating selling prices at output. Therefore, it is necessary to have policies to improve the production efficiency of poor farmers through measures to increase training and create conditions for farmers to access capital for tea cultivation.

Thirdly, although farmers are the agents with the highest profit margins in the value chain, due to the slow capital turnover time and low production output of households, the investment efficiency is the lowest in the value chain. In contrast, with relatively high profit margins, large trading volumes and fast turnover, wholesalers are the most effective investment actors in the value chain. In order to increase profits for actors in a mutually beneficial manner, it is neces- 
sary to have forms of chain linkage to minimize unnecessary costs.

\section{Conflicts of Interest}

The authors declare no conflicts of interest regarding the publication of this paper.

\section{References}

[1] Dastagiri, M.B. (2017) Analysis of Economic Trends in Overseas Markets for Indian Tea and Coffee. Outlook on Agriculture, 46, 44-48. https://doi.org/10.1177/0030727016689736

[2] Grigg, D. (2002) The Worlds of Tea and Coffee: Patterns of Consumption. GeoJournal, 57, 283-294. https://doi.org/10.1023/B:GEJO.0000007249.91153.c3

[3] ADB (2004) The Value Chain for Tea in Viet Nam: Prospects for Participation of the Poor. Making Markets Work Better for the Poor. Discussion Paper.

[4] Committee, T. N. P. P. s. (2017) Summary Report on Development of Tea Industry in Thai Nguyen Province.

[5] Department of Natural Resources and Environment of Thai Nguyen (DNRE) (2019) General Report.

[6] Lu, H. (2006) A Two-Stage Value Chain Model for Vegetable Marketing Chain Efficiency. The International Association of Agricultural Economists Conference, Queensland, 12-18 August 2006, 1-16.

[7] Huque, S.M.R. (2007) Strategic Cost Management of Tea Industry: Adoption of Japanese Tea Model in Developing Country Based on Value Chain Analysis. Yokohama National University Repository.

[8] Leahu, V. (2011) Moldovan Apple Value Chain Study.

[9] Khai, T.T. (2011) Ben Tre Coconut Value Chain Analysis Report.

[10] Son, N.P. (2012) Value Chain Analysis of Apples, Garlic and Grapes in Binh Thuan Province.

[11] Kiet, T.H.V.T. (2014) Analysis of Hoa Loc Mango Value Chain of Dong Thap Province. Science Journal of Can Tho University. Part D: Political Science, Economics and Law, 35, 32-39.

[12] Loc, V.T.T. (2015) Value Chain Analysis of Thanh Long in Cho Gao District, Tien Giang Province. Scientific Journal, Can Tho University, 36, 10-22.

[13] Pavithra, A.S., Nasim Ahmad, K.M.S., Sinha, D.K. and Mishra, R.R. (2018) Economic Analysis of Rice Value Chain in Bihar and Karnataka States of India. International Journal of Current Microbiology and Applied Sciences, 7, 2738-2278. https://doi.org/10.20546/ijcmas.2018.703.316

[14] Parmar (2019) Economic Analysis of Rainfed Maize Production in Central Gujarat, India. International Journal of Current Microbiology and Applied Sciences, 8, 2420-2429. https://doi.org/10.20546/ijcmas.2019.808.281

[15] Sanga, D.A. (2016) Value Chain and Rural Livelihoods: Analysis of Acacia mearnsii (Black Wattle) Activities in Njombe and Lushoto Districts. Sokoine University of Agriculture, Morogoro.

[16] Doanh, N.K., Thuong, N.T.T. and Heo, Y. (2018) Impact of Conversion to Organic Tea Cultivation on Household Income in the Mountainous Areas of Northern Vietnam. Sustainability, 10, 1-21. https://doi.org/10.3390/su10124475 
[17] Empowerment, C. f. C. (2007) Comparative International Research on the Tea Sector in Vietnam.

[18] Gurusubramanian, G., Rahman, A., Sarmah, M., Ray, S. and Bora, S (2008) Pesticide Usage Pattern in Tea Ecosystem, Their Retrospects and Alternative Measures. Journal of Environmental Biology, 29, 812-826.

[19] Ahmad, F., Sarwar, S., Waheed, A., Aslam, S. and Islam, S. (2010) Effect of Different Pruning Times on the Yield of Tea (Camellia sinensis L.) under the Climatic Conditions of Mansehra-Pakistan. Sarhad Journal of Agriculture, 30, 305-309.

[20] Vietnam Tea Association (VITAS). http://fairtrade.org.vn/english/129.html

[21] Vietnam Tea Association (VITAS) http://tea-vietnam.vn/en/about-us.html 